\title{
Global Standards, Corporate Diagrams and Indigenous Agency: ExxonMobil in Russia and Alaska
}

\author{
Maria S. Tysiachniouk ${ }^{\star}$ \\ Department of Geographical and Historical Studies, University of Eastern Finland, Finland \\ Environmental Policy Group, Wageningen University, the Netherlands \\ Nelson Institute for Environmental Studies, University of Wisconsin-Madison, USA \\ Centre for Independent Social Research, Russia
}

\section{Laura A. Henry \\ Department of Government and Legal Studies, Bowdoin College, USA}

\section{Leah S. Horowitz}

Nelson Institute for Environmental Studies and School of Human Ecology, University of Wisconsin-Madison, USA

\begin{abstract}
This paper examines how a transnational corporation (TNC) translates global standards and corporate policies into programs at sites of extraction. We explore this question through a comparative analysis of ExxonMobil's operations in two different politico-economic contexts: the Sakhalin-1 project in Russia and the Point Thomson project on the North Slope of Alaska, with field work on Sakhalin Island in 2013-2015 and in Alaska in 2015-2018. Theoretically, we use the Deleuzian concept of "diagram" as a lens through which to examine corporate policies, and a governance generating network (GGN) approach to analyze similarities and differences in benefit-sharing programs in both localities. We show that while global commitments and corporate principles contribute to a standardized approach to community engagement, Indigenous movements and associations, the government, and other corporate actors may play important roles in influencing how corporate policies and global standards are implemented at sites of extraction. Moreover, adaptation of community engagement, benefit-sharing, and environmental monitoring in one location may shape how the company's strategies are implemented in other sites of extraction.
\end{abstract}

\footnotetext{
^Correspondence to: Maria S. Tysiachniouk, e-mail: Maria.Tysiachniouk@uef.fi

(C) 2022 Maria S. Tysiachniouk, Laura A. Henry and Leah S. Horowitz. This is an Open Access article distributed under the terms of the Creative Commons CC-BY 4.0 License. eISSN 2387-4562. https://arcticreview.no.

Citation: Maria S. Tysiachniouk, Laura A. Henry and Leah S. Horowitz. "Global Standards, Corporate Diagrams and Indigenous Agency: ExxonMobil in Russia and Alaska” Arctic Review on Law and Politics, Vol. 13, 2022, pp. 1-31. http://dx.doi.org/10.23865/arctic.v13.3549
} 
Keywords: Sakhalin Island, Alaska North Slope, Arctic, benefit-sharing, corporate social responsibility, governance generating networks, transnational corporations, nongovernmental organizations, global standards, Indigenous peoples

Responsible Editor: Øyvind Ravna, Faculty of Law, UiT The Arctic University of Norway

Received: October 2021; Accepted: January 2022; Published: February 2022

\section{Introduction}

How do transnational corporations (TNCs) translate global standards and corporate policies into programs at sites of extraction? TNCs, by definition, operate simultaneously in many countries, encountering different political, legal, and social contexts. TNCs ostensibly are guided by corporate policies, corporate social responsibility principles, and commitments to international conventions on issues ranging from the environment to labor rights and Indigenous rights. ${ }^{1}$ But to what degree does the implementation of a TNC's international and corporate commitments vary depending on the local context? We explore these questions through a comparative analysis of ExxonMobil's operations in two very different political and economic contexts: the Sakhalin-1 project in Russia and the Point Thomson project on the North Slope of Alaska, locations where the company engages Indigenous peoples who live proximate to territories of extraction.

Over time and under pressure from non-governmental organizations (NGOs), international financial institutions have incorporated global social and environmental standards into their investing and lending requirements, paying particular attention to Indigenous rights. ${ }^{2}$ Global conventions and corporate social responsibility (CSR) policies are meant to ensure that local communities can influence how extraction occurs and in some way benefit from it, and also to ensure environmental protection. ${ }^{3}$ Benefit-sharing represents the distribution of monetary and non-monetary benefits generated by TNCs' resource extraction to affected Indigenous and local communities. ${ }^{4}$ A TNC's CSR policies are, in part, designed to avoid conflict and reputational damage through community engagement. However, a TNC's commitment to CSR principles does not guarantee effective community consultation or fair and equitable benefit-sharing arrangements with Indigenous peoples living near the company's operations. ${ }^{5}$ How standards and policies are implemented will depend in part on how they are developed in corporate offices, adapted to local conditions, and changed over time.

This paper examines how ExxonMobil implements its global commitments and corporate policies in Indigenous communities near sites of extraction in two very different political and social contexts. Specifically, we investigate ExxonMobil's policies related to community engagement and benefit-sharing -- ranging from charitable support to resource transfers to Indigenous peoples. We use a governance generating 
network (GGN) approach to analyze the sources of similarities and differences in corporate-community relations. The GGN framework draws attention to negotiations among multiple actors over the meaning of global standards and corporate policies and how they are implemented, including opportunities for feedback and resistance.

We find that, despite starkly different political and economic contexts in Russia's Sakhalin Island and the U.S. state of Alaska, ExxonMobil used markedly similar strategies to engage Indigenous peoples, based on a "diagram" of standardized policies and programs, ${ }^{6}$ derived in part from global conventions related to the rights of Indigenous peoples. However, the implementation of these policies in each territory of extraction was shaped by local factors, including differences in national law and ownership, and mediation by Indigenous institutions and resistance and protest by Indigenous communities. The diagram of standardized programs may also change over time. Ultimately, we argue that, while TNCs prefer consistent policies to reduce transaction costs and manage risks, Indigenous movements and associations, governments, and other corporate actors all play important roles in adapting corporate programs based on global standards to specific localities.

\section{Corporate Diagrams within a Governance Generating Network: The Theoretical Approach}

Energy companies engaged in extraction pose particularly acute cost-benefit questions for nearby communities. ${ }^{7}$ While distant populations benefit from the use of energy resources, communities located proximate to sites of extraction may face disproportionate environmental and health effects and disruptions to traditional ways of life. For Indigenous peoples, extraction may damage traditional cultural and economic activities, such as hunting, fishing, whaling, and foraging. ${ }^{8}$

Given a TNC's primary focus on profit and shareholder value, CSR principles are intended to hold TNCs accountable for environmental and social impacts. Resistance and conflict around extraction creates risks of reputational damage which generates pressure for TNCs to adhere to CSR principles. ${ }^{9}$ In response, TNCs publicize their commitment to global standards and develop their own corporate policies regarding social and environmental responsibility. Yet whether corporate social responsibility principles go beyond public relations and are implemented as practices on the ground remains under-examined.

Theoretically, we use the concept of a governance generating network (GGN), in conversation with the Deleuzian concept of "diagram", to consider how networks around oil extraction, including transnational energy companies and local subsidiaries, financial institutions, and investors interact with government agencies and civil society actors, such as Indigenous peoples and environmental NGOs, in various forums. ${ }^{10}$ The concept of diagram draws our attention to the way in which complex streams of thought around corporate responsibilty interact and produce a simplified, standardized, and generalized orientation toward community and Indigenous relations. A GGN 
analysis draws attention to how territories of extraction are governed by networks of actors at multiple scales and represents a range of shifting relationships between actors involved in the design, transfer and implementation of new rules. ${ }^{11}$ Each GGN consists of three main components: transnational nodes of global governance design, forums of negotiation, and sites of implementation (see Figure 1). The development of rules and standards for the extractive industry takes place in transnational nodes of design. Non-binding conventions, such as the United Nations Declaration on the Rights of

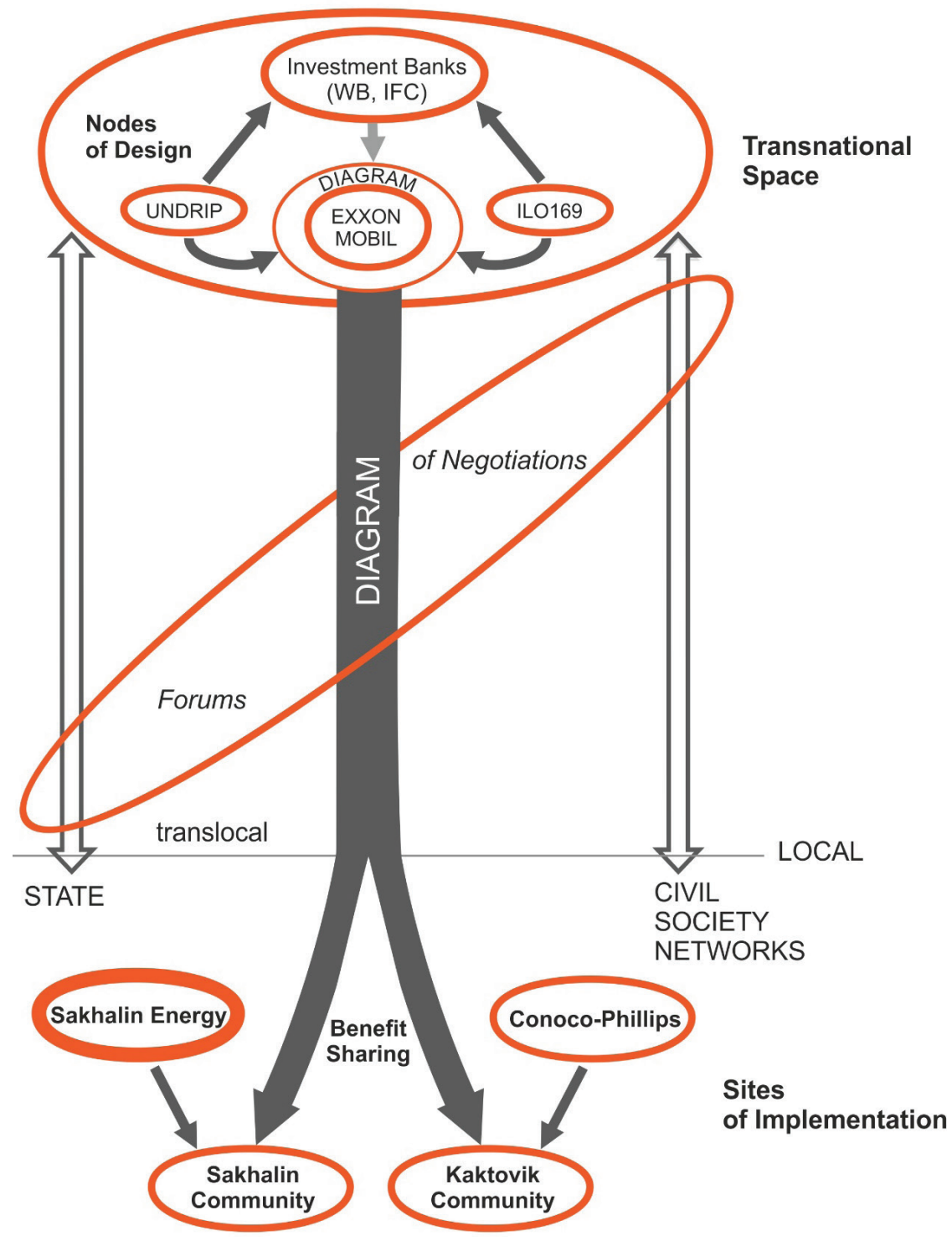

Figure 1. ExxonMobil Diagram and Governance Generating Network 
Indigenous peoples (UNDRIP) and the Arctic Council's (AC) Offshore Oil and Gas Guidelines, attempt to foster sustainable production practices that protect the rights of Indigenous peoples from the negative impacts of extraction. The Extractive Industry Transparency Initiative (EITI), IPIECA, and the International Monetary Fund (IMF), the International Financial Corporation (IFC), the World Bank (WB), and the European Bank of Reconstruction and Development (EBRD) also develop standards for TNCs, some as recommendations and others as requirements.

Sites of implementation are locations where energy companies explore for, extract, and transport resources, and construct infrastructure. These sites are where rules and standards are put into practice and adapted to the specific contexts of local communities. Forums of negotiation connect sites of implementation to transnational nodes of design (e.g. TNC corporate offices, investment banks, and/or international institutions). Through these forums, private, state, and civil society actors negotiate changes in global rules and standards or their implementation practices (see Figure 1). Within a GGN, civil society campaigns may transmit grievances from sites of implementation to global institutions, such as international financial institutions or UN forums, and attempt to introduce issues to global agendas or to change practices in sites of implementation. In turn, TNCs both accommodate and foster institutional changes locally as they implement global standards. ${ }^{12}$

In adopting global standards and developing their own corporate policies, TNCs themselves become nodes of global governance design. A TNC's standardized approach to developing implementation strategies that adhere to global conventions and their own policies can be understood as a "diagram" - the creation of an abstract "map of relations between forces,"13 the development of a repertoire of strategies, and a generalized framing of a problem and series of steps for addressing it. ${ }^{14}$ Once created, a diagram can be transferred from one context to another, as long as the "problem" appears similar. ${ }^{15}$ For our analysis, we use the concept of diagram to describe the way in which a TNC streamlines and simplifies diverse approaches to issues of corporate-community relations (specifically benefit sharing and environmental management) and develops an abstract set of orientations and policies that both articulate and attempt to "solve" the problem, then applying the diagram in territories of extraction. As nodes of global governance design, TNCs disseminate governance arrangements that shape relations with stakeholders and prescribe programs at sites of implementation. Standardized approaches help TNCs to avoid transaction costs while operating in multiple countries. ${ }^{16}$

At the same time, however, TNCs must adapt CSR strategies to the context of sites of implementation. TNCs prefer stable interactions to facilitate long-term risk management, as any disruption or reputation damage could result in a loss of profit. Therefore, economic "actors try to produce a 'local' stable world" that allows them to "reproduce their advantage" 17 from one site of implementation to another. As we demonstrate, such stability requires a TNC not simply to impose a prescribed diagram of community engagement policies but to develop a strategy 
of adaptation to local political, economic, cultural, and environmental conditions. This adaptation is shaped by pressures from stakeholder groups, including Indigenous communities, environmental activists, and government representatives. We explore the degree to which various institutions and stakeholder groups influence the diagram's adaptation from sites of implementation to forums of negotiation and transnational nodes of design, with a particular focus on benefit-sharing, or the distribution of monetary and non-monetary benefits generated through resource extraction activity. ${ }^{18}$

\section{Methodology}

Data for this study was gathered by the primary author on Sakhalin Island in 20132015 during two periods of field work and on Alaska's North Slope in 2015-2018 during three periods of field work. Qualitative research methodologies, including semi-structured interviews, participant observation, and document analysis, were the primary means of data collection. Separate interview guides were created for Sakhalin and the North Slope for company representatives, Indigenous leaders, NGO representatives, and government officials. Each interview took thirty to ninety minutes. Interviews focused on the interaction between companies and Indigenous people as well as the implementation of global standards and benefit-sharing arrangements. The interviews were transcribed and coded. We also analyzed a variety of documents pertaining to ExxonMobil's CSR policies, Global Reporting Initiative reports, and other publications related to corporateIndigenous relations, in order to compare ExxonMobil's programs in both Sakhalin and the North Slope.

In Sakhalin, 63 interviews took place with a variety of actors in YuzhnoSakhalinsk and villages such as the Okha and Nogliki municipal districts, where Exxon Neftegas Limited (ENL) operates (Appendix A). Interviews were conducted with the following groups: representatives of ENL, Rosneft, and Sakhalin Energy; regional and municipal government officials; NGO representatives; representatives of Indigenous peoples' associations; local residents; and scientists. In Alaska, 67 interviews were conducted in Fairbanks and Anchorage at gatherings of Indigenous peoples, and in North Slope villages. The village of Kaktovik was chosen as the primary research site due to its proximity to ExxonMobil's Point Thomson project. Interviews also were conducted at the regional center Utqiagvik and at Nuiqsut, the village most affected by oil extraction by companies other than ExxonMobil, to better understand the context on the North Slope (Appendix B). Interview subjects included representatives of local, state and federal government agencies; scientists; Indigenous leaders from regional and local village corporations, Indigenous and non-Indigenous community representatives; corporate consultants; and representatives of oil companies that operate on the North Slope, including ExxonMobil, Conoco-Phillips, and British Petroleum. 
In addition, interviews were conducted in Houston with representatives from ExxonMobil and Conoco-Phillips.

\section{ExxonMobil on the Ground: Extraction and Indigenous peoples in Sakhalin and Alaska}

ExxonMobil is a profit-driven corporation dedicated to maximizing value for shareholders; however, the TNC is also a node of global governance design that claims to pursue a "triple bottom line" focused on profit, people and planet. ${ }^{19}$ Scholarly research chronicles the development of ExxonMobil's approach to corporate social responsibility, including its efforts at community engagement ${ }^{20}$ and resulting challenges. ${ }^{21}$ ExxonMobil has adopted a range of global conventions as well as developed its own corporate policies and codes of conduct to guide its interactions with Indigenous peoples; the TNC frequently reiterates these commitments in its public relations materials. For example, ExxonMobil has committed to the International Finance Corporation (IFC) Performance Standards on Environmental and Social Sustainability, the World Bank Operational Policy and Bank Procedure on Indigenous peoples, and the IPIECA oil and gas industry association's environmental and social performance programs. ${ }^{22}$ ExxonMobil implemented ISO Standard 26000 on social responsibility. In addition, corporate documents reference the UN Declaration on the Rights of Indigenous peoples (UNDRIP) and ILO Convention 169 Concerning Indigenous and Tribal peoples which recognizes "the aspirations of [Indigenous] peoples to exercise control over their own institutions, ways of life and economic development." In its policy statement on Indigenous peoples, ExxonMobil declares, "We respect Indigenous peoples and their cultures, commit to conducting meaningful consultations with them, incorporate traditional knowledge and land use information into our plans and seek mutually beneficial longterm relationships." 23

As a node of governance, ExxonMobil's policies apply to its network of whollyowned and majority-owned subsidiaries, connecting sites of implementation around the world, ${ }^{24}$ using a diagram of community engagement and benefit-sharing policies. Given that ExxonMobil operates in many countries and regions simultaneously, it faces pressure to adapt its policies to fit the contexts of the various sites of implementation and to comply with national laws and regulations, and take into account informal local practices. It remains an open question how and to what degree this adaptation of corporate policies and programs occurs.

In the sections that follow, we first describe two ExxonMobil projects and the Indigenous communities that live proximate to these sites of extraction. We then determine the degree to which the TNC has applied its diagram of similar policies despite clear differences in each case. Finally, we examine how these varied contexts have shaped local implementation of the company's diagram of community-engagement policies. 


\section{Results}

\subsection{Exxon Neftegas Limited in Russia: The Sakhalin-1 project and Indigenous Communities}

Sakhalin Island is situated off the east coast of Russia in the Sea of Okhotsk. Sakhalin has a population of roughly 511,000 residents, of whom approximately 3,000 are Indigenous peoples. ${ }^{25}$ Villages inhabited by Indigenous peoples in two municipal districts are situated in proximity to extractive infrastructure: Nogliki district which has six villages with 1135 Indigenous residents; and Okha district, which has five villages with 1457 Indigenous residents from the Nivkh, Uilta, Nanai, and Evenk peoples. Some of these Indigenous people participate in an obshchina, an Indigenous organization involved in traditional economic activities, such as fishing, reindeer herding, hunting, foraging, and artistic work.

In 1993, Exxon Neftegas Limited (ENL), a subsidiary of ExxonMobil, began the Sakhalin-1 oil and gas development project in an agreement with the Japanese company SODECO. It is owned by ENL (30\%), SODECO (30\%), RN-Astra (8.5\%) and Sakhalinmorneftegaz-Shelf (11.5\%) (both affiliates of state-owned Rosneft Company), and India's Oil and Natural Gas Corporation ONGCVidesh Ltd (20\%). Sakhalin-1 represented one of the largest foreign direct investments in Russia at that time. ${ }^{26}$ In 1996, the companies and the Russian government signed a production sharing agreement. Construction started in 2004, and the first oil was produced in $2010 .{ }^{27}$ As of 2018, the project had exported 100 million tons of crude oil. The complex includes onshore and offshore oil rigs as well as processing facilities and shipment terminals. There is a second large oil and gas consortium on the island: Sakhalin-2, operated by Sakhalin Energy, a partnership of Royal Dutch Shell, Mitsui, and Mitsubishi Corporation. In 2007, Gazprom bought a 50\% plus 1 share in Sakhalin Energy from Royal Dutch Shell.

\subsection{ExxonMobil in Alaska: The Point Thomson Project and Indigenous Communities}

Point Thomson is an oil and gas project historically operated by ExxonMobil (with a $62 \%$ share), with stakes also held by British Petroleum (32\% share) and Conoco Phillips (5\% share, sold in 2017), with a handful of other minority shareholders who left the project over the years. ${ }^{28}$ Point Thomson is located 60 miles east of Prudhoe Bay and 60 miles west of the village of Kaktovik. The project borders the Arctic National Wildlife Refuge's northwestern corner. Point Thomson has received $\$ 4$ billion in investment from ExxonMobil ${ }^{29}$ Construction started in 2008, pipelines were built in 2013, production modules were installed in 2014-2016, and production began in 2016. Point Thomson produces natural gas condensate, which then travels by pipeline to the Trans-Alaska Pipeline System. ${ }^{30}$ The project is estimated to contain over 226.5 billion cubic feet of natural gas, 25 percent of the North Slope's proven natural gas reserves. ${ }^{31}$ 
Global Standards, Corporate Diagrams and Indigenous Agency

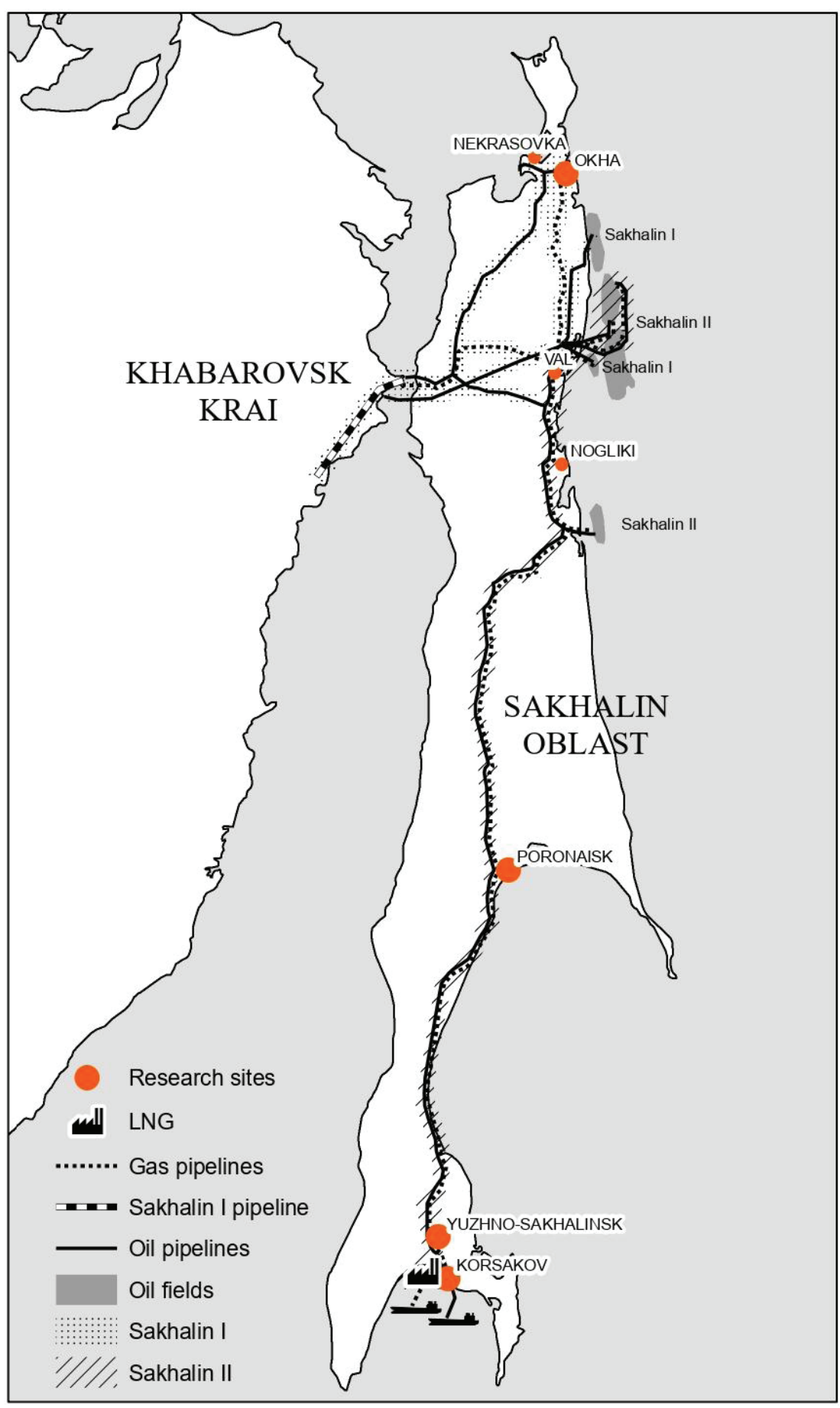

Figure 2. Map of Sakhalin Island, Russian federation 


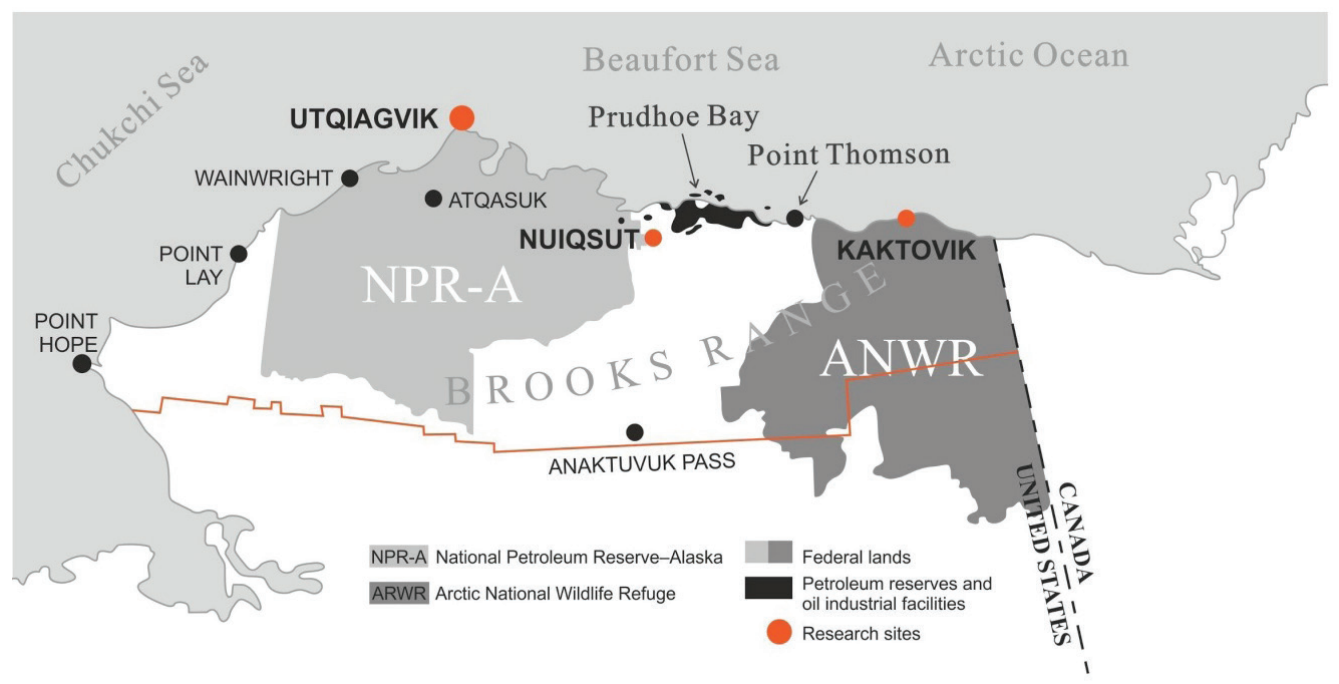

Figure 3. Map of the North Slope of Alaska

The village of Kaktovik (Inuuniagviat Qaaqtuvigmiut) is situated on Barter Island, adjacent to the Arctic National Wildlife Refuge (ANWR), and accessible only by air or boat. The Kaktovik Inupiat have been living in the area for thousands of years, but year-round settlement of the area in the modern era began in the 1920s. As of 2016, the village had 262 residents. ${ }^{32}$ Through passage of the 1971 Alaska Native Claims Settlement Act (ANCSA), Alaska Native Corporations were granted either surface rights (the Kaktovik Iñupiat Corporation, at the village level) or both surface and subsurface property rights (the Arctic Slope Regional Corporation (ASRC)). ${ }^{33}$ However, the federal government retained control of significant portions of land, including the Arctic National Wildlife Refuge. Local residents are simultaneously involved in market and subsistence economies, including tourism related to polar bear viewing ${ }^{34}$ and hunting marine mammals, such as bowhead whales, walrus, and seal, as well as caribou. Prior to the Point Thomson installation, Kaktovik residents had not been directly exposed to the effects of oil development.

\subsection{Adapting Global Standards and Corporate Policies to Local Conditions}

ExxonMobil has constructed a diagram of standardized corporate policies that extend from its node of global governance design towards sites of implementation. These policies guide its engagement with Indigenous communities in benefit-sharing. The company's actions in two sites of extraction demonstrate the tensions between maintaining a standardized approach and the need to address local conditions. First, 
in both cases the company centers its benefit-sharing around grant programs to support traditional economic activities and Indigenous cultural activities, although these programs are implemented differently in the two sites. In addition, in both cases, ExxonMobil consistently supports STEM education for Indigenous youth through grants, as well as through the provision of resources and equipment for health and education programs from the company directly. Second, ExxonMobil employs Indigenous community liaisons to serve as intermediaries who distribute information on company projects and grant applications, collect grievances, and organize community consultations. However, few Indigenous workers from the villages are hired by the company to work on the extractive projects. Finally, the company employs Indigenous wildlife monitors to assess environmental impacts on Indigenous traditional economic activities - salmon fishing and some reindeer herding on Sakhalin and caribou and whale hunting in Kaktovik.

\subsection{Benefit-Sharing Policies}

A broad view of benefit-sharing encompasses transfers of resources from extractive industries to Indigenous peoples in forms ranging from the distribution of tax revenues to employment and community grants. Some benefit-sharing arrangements fulfill commitments made in a TNC's global node of governance design, while others are developed at the request of local stakeholders. We review these areas below.

Taxation is one aspect of benefit-sharing. The Sakhalin-1 project has generated over $\$ 16$ billion for the Russian government in the form of lease, tax and royalty payments, including more than $\$ 6.6$ billion to the Sakhalin regional budget. ${ }^{35}$ ExxonMobil pays taxes to the U.S. federal and Alaskan state governments and to the North Slope Borough (NSB) for its infrastructure in Prudhoe Bay. In both sites, significant tax revenue flows to regional governments -- in Alaska to the NSB, and in Sakhalin, ExxonMobil and Sakhalin Energy signed a production sharing agreement which provides funding to the regional government instead of the federal until their initial investments are paid.

Indigenous organizations are more directly involved in the distribution of tax revenues in the North Slope than in Sakhalin. Kaktovik residents receive tax revenue from oil companies, including ExxonMobil, through redistribution by the NSB and the state of Alaska. In 2019 the NSB spent $\$ 77.8$ million on infrastructure and services - such as airports, landfills, natural gas infrastructure - for eight villages, including Kaktovik. ${ }^{36}$ The NSB also provides emergency services, road maintenance, utilities and medical services, finances village schools and a college in Utqiagvik. ${ }^{37}$

Employment is one possible ancillary benefit for communities at sites of extraction. However, employment numbers tend to be modest in both cases. ENL asserts that since 2002, almost 300 Russian citizens, mostly from the city of Yuzno-Sakhalinsk have been trained and hired as technicians on Sakhalin. As mentioned above, the company also employs Indigenous people as community liaisons and environmental 
monitors of the salmon and gray whale populations. In Alaska, with the exception of wildlife monitors, ExxonMobil only employs four Indigenous people from Kaktovik. ${ }^{38}$

Central to the diagram designed to implement ExxonMobil's corporate governance commitments are benefit-sharing programs in the form of grant programs in both locations. The programs to channel resources to the communities are similar in principle, but take slightly different forms in the two regions. In Sakhalin, a grant program overseen by a tripartite partnership (comprised of representatives from the company, the Sakhalin regional government, and the Indigenous peoples) has developed over time, suggesting that regional government officials play a more significant role in company-community relations in Russia than in Alaska. In Kaktovik, ExxonMobil helped found the Kaktovik Community Foundation (KSF), run by an Indigenous manager based in Anchorage to play a similar role in channeling funding for community projects. Anyone can contribtue to the KCF, but in practice ExxonMobil has primarily used it to transfer resources to the community.

In Sakhalin, the grant program developed over time as ENL's initial focus on compensation for damages shifted first to an informal funding arrangement between the company and the Association of Indigenous Peoples of Sakhalin Oblast [Region] and finally developed into a tripartite system of consultation between the company, government officials, and Indigenous representatives. ENL employs six Indigenous liaisons (two from Yuzhno-Sakhalinsk and four from nearby villages) to facilitate the grant program and to serve as intermediaries between the company and local community. Since the start of the Sakhalin-1 project, the consortium has contributed over $\$ 35$ million for more than 1500 social projects (Sakhalin-1). ${ }^{39}$ Indigenous representatives participate in the grant awarding committee, which consists of representatives from the government, the company and Indigenous Peoples. Routine participation in grant decisions has facilitated the institutionalization of Indigenous organizations over time, and stimulated growth in the number and capacity of Indigenous NGOs and obshchinas. ${ }^{40}$ For example, the NGO Kihk-Kikh, which is formally registered as a non-profit, receives grant funding itself and also serves as an intermediary to channel resources to other small Indigenous culture groups. In Sakhalin the consortium contributed significantly to transportation and social infrastructure during the early stages of the Sakhalin-1 project, including the construction and/ or modernization of roads, bridges, hospital equipment, and an airport in Nogliki, some of which the company needed to support its own operations. ${ }^{41}$ The Sakhalin-1 consortium, including ENL, provides charitable support for education, healthcare and culture, ${ }^{42}$ with all companies contributing to STEM education (a global priority for ExxonMobil) such as the Eureka project for high school students and annual participation in the All-Russia School Olympic games. ${ }^{43}$

As mentioned above, KCF was established by ExxonMobil prior to the start of the Point Thomson project to channel resources to the area. ${ }^{44}$ The foundation, which is technically independent but relies on ExxonMobil as its primary funder, for example, used $\$ 120,000$ from the company to install new storage cellars for 
the community to preserve traditional foods as warming temperatures and coastal erosion have threatened traditional ice cellars. ${ }^{45}$ Currently, the KCF supports local college students by providing approximately six scholarships annually for two- or four-year degree or vocational training programs. ${ }^{46}$ Students who receive a STEM education have the opportunity to seek employment at the Point Thomson project. The KCF also plans to construct a new museum and cultural center. ${ }^{47}$ Villagers mention several important benefits that the community receives from ExxonMobil, including donated funds for education, a seismic test to identify gravesites on the western edge of the island, and support for the community's Nalukatak celebrations following successful whaling expeditions.

The Point Thomson project also employs a local community liaison who works part-time, assisting with meetings and relaying concerns. ${ }^{48}$ According to one municipal leader, representatives from the Point Thomson project work with the community more effectively than other oil companies. However, the same leader also points out that "We always are very meticulous in talking to oil corporations, because they are prone to giving false promises." ${ }^{49}$ Despite numerous meetings held between the Native Village of Kaktovik, the incorporated city of Kaktovik, and Alaska Native Corporations to discuss oil development in Kaktovik, a community leader who is generally satisfied with the interaction with ExxonMobil suggests there is a need for even more communication. ${ }^{50}$

ExxonMobil often publicizes its commitment to respecting Indigenous cultures. ENL, as a subsidiary, has highlighted its role in revitalizing Indigenous cultures by sponsoring festivals and holidays for Sakhalin communities. The majority of grantfunded projects focus on Indigenous culture and traditions, such as sponsoring Indigenous artists' travel to Moscow and abroad and helping to support native languages. For example, ENL contributed to the Okha Art museum and purchased traditional Indigenous objects and display cases (Sakhalin-1, 2019a). In Kaktovik, the company held discussions with the tribal government (the Native Village of Kaktovik) and the community on projects related to cultural resources, including the digital mapping of an eroding cemetery. ${ }^{51}$ In a widely publicized project, Exxon transferred historical Kaktovik artifacts from the Canadian Museum of History to the Museum of the North at the University of Alaska, Fairbanks. ${ }^{52}$ The company then organized transportation for community members' to travel to Fairbanks to see these artifacts..$^{53}$

Environmental protection is another component of ExxonMobil's diagram..$^{54}$ The environmental commitments expressed in various corporate policies are based on international agreements and guidelines as well as local stakeholders' demands. A persistent concern among Indigenous peoples on Sakhalin has been the impact of extraction on salmon migration and spawning grounds. ${ }^{55} \mathrm{ENL}$ employs Indigenous people in temporary positions at the exploration stage of project development to monitor wildlife populations; in Kaktovik wildlife monitors are employed annually during the whaling season. In response to legal requirements from the U.S. Fish and Wildlife Service and stakeholder requests, ExxonMobil also sponsors significant monitoring of species such as caribou and polar bear, vegetation, and fish populations 
as well as water levels on Alaska's North Slope. The Point Thomson project conducts biannual meetings to communicate with the local community, where project representatives explain how the operations will develop and answer questions about possible impacts on wildlife. At some of these meetings, the community has also raised broader issues related to benefit sharing.

\section{Discussion: Explaining Similarities and Differences in Patterns of Indigenous Engagement}

These case studies demonstrate that ExxonMobil has a repertoire of strategies a diagram - developed in its node of governance designed to engage Indigenous communities near sites of oil extraction. Athough the headquarters of ExxonMobil is located in Irving, Texas, the concept of a node of governance design centered around a TNC trascends a single geographic location and encompasses corporate units located in Houston, Washington DC, Anchorage and Fairbanks. The repertoire of strategies deveoped in this node include grant programs to community organizations, community liaisons, educational and cultural support, and the employment of Indigenous wildlife monitors. The TNC's programs are similar across distant geographies, both in benefit-sharing and environmental monitoring (see Figure 4). However, despite these commonalities, there are important differences in how ExxonMobil works with Indigenous communities in Russia and the US due to the contexts of the sites of implementation. One difference is simply that Sakhalin-1 is

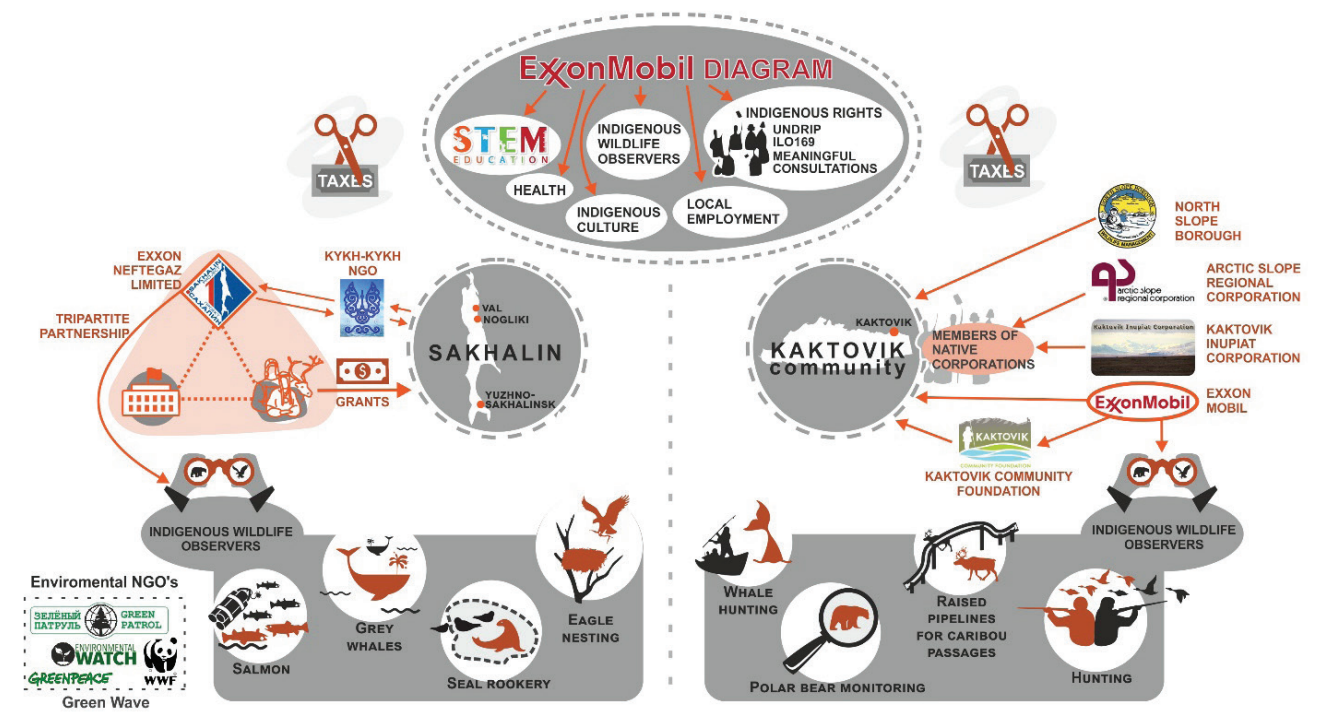

Figure 4. ExxonMobil Diagram Implementation in Sakhalin Island and Kaktovik 
a much larger project that started fifteen years prior to the development of Point Thomson. Other variations in the implementation of the company's standardized approach are shaped by national and regional laws, by specific stakeholders, and at times by the policies of other members of the consortia or other TNCs operating in the region. The diagram also changes over time in response to Indigenous resistance. Below we explore sources of similarity, changes over time, and adaptations to local conditions, briefly considering the ownership of land or mineral rights, national laws related to Indigenous peoples, Indigenous self-governance institutions, Indigenous agency and activism, cooperation with environmental NGOs, and finally pressure toward isomorphism with the policies of other TNCs.

\subsection{Standardizing Extractive Projects: Lowering Transaction Costs and Risks}

As a node of global governance design, a TNC adopts commitments from other global nodes and develops a standardized set of policies and programs to engage Indigenous communities. This standardized approach is designed in part to reduce the costs of project development and to minimize risks of community opposition. As a for-profit enterprise, ExxonMobil's commitment to global standards in its corporate policies and programs is an aspect of risk management. For ExxonMobil, a key source of similarity across geographic sites of implementation is the use of a team of specialists to initiate new projects, regardless of their location. The ExxonMobil Development Company employs community relations experts who specialize in the construction stage of project development and who move from country to country over the course of their careers. These experts are charged with upholding corporate standards and ensuring that the company complies with the rules and regulations at the site of implementation ${ }^{56}$ and develops best practices to apply to each successive project. ${ }^{57}$ A primary objective of this work is to minimize the risk of negative publicity by engaging in benefit-sharing, community outreach, and philanthropy. As one ExxonMobil representative stated, "One of the first things I was taught was that I wasn't joining an oil and gas development company as much as I was joining a risk management company." ${ }^{58}$ Still, some global standards are more likely to be upheld than others. For example, ExxonMobil rarely mentions the principle of Free, Prior and Informed Consent (FPIC) it its Citzenship and Sustainabilty reports, even though this principle is endorsed in both UNDRIP and the ILO nodes of global governance. Regarding both Sakhalin-1 and Point Thomson, ExxonMobil has only relied on consultations with communities and community liaisons.

\subsection{Land, Minerals, and Self-Governance}

Differences in the ownership of land and mineral rights and in governance institutions can shape the implementation of the diagram. In Sakhalin, as elsewhere in Russia, all land and mineral resources are owned by the state; therefore, Indigenous peoples' involvement in natural resource management is limited..$^{59}$ The laws that 
guide public participation in oil development, and specifically Indigenous participation, are the 1993 Russian Constitution (notably Article 19), the Law on Ecological Expertise, and the Land Code. These laws are applicable to all citizens, not exclusively to Indigenous populations. Under Law No. 82-FZ On the Guarantee of the Rights of Indigenous peoples of the Russian Federation (1999), Indigenous people may receive compensation for land damaged by extractive industries if the land has been designated as a territory of traditional nature use; in some cases, regional governments have developed regulations requiring compensation. However, these rules are not in effect on Sakhalin where state-owned lands are shared among multiple users. Instead, Sakhalin's Indigenous fishermen, reindeer herders and hunters participate in benefit-sharing arrangements with companies. ${ }^{60}$ Indigenous enterprises in Sakhalin tend to be small, family-based entities. In contrast, Alaska Native Corporations are powerful for-profit entities that may own significant land and mineral resource rights. Under ANCSA, Alaska Native people were allowed to join Alaska Native Corporations - one at the village level and one at the regional level. Residents born before 1971 received 100 shares that can be inherited or gifted ${ }^{61}$ while Alaska Native Corporations could choose to distribute shares to those born after $1972 .{ }^{62}$ For the Point Thomson project, ExxonMobil has a contract for services with the Indigenous-led ASRC in Prudhoe Bay. Almost all Indigenous residents of Kaktovik are ASRC shareholders and therefore receive indirect benefits from ExxonMobil. In 2019, in ASRC the dividend per share was $\$ 70$, a significant sum, especially for families with children, but in 2021 annual distribution declined to $\$ 40$ per share. ${ }^{63}$ Kaktovik residents also receive shares from the Kaktovik Inupiat Corporation, which has some limited contracts with ExxonMobil. Relative financial support to Indigenous communities on Sakhalin tends to be much lower than on the North Slope.

The number and type of Indigenous organizations and institutions that play a role in governing local communities and natural resources or advocating on behalf of Indigenous peoples differ in the two cases. The North Slope of Alaska is characterized by multilayered governance with a high level of self-government and Indigenous leadership. In the Alaskan case, the North Slope Borough is a municipality with an elected leadership that is primarily Indigenous. It has the authority to tax energy company infrastructure in Prudhoe Bay. In addition, multiple federal agencies, such as the Bureau of Land Management and Fish and Wildlife Service, are involved in the governance of natural resources on federal lands and waters. Compared to the North Slope of Alaska, Sakhalin hosts few Indigenous-led institutions involved in the governance of natural resources. In Sakhalin, the regional government is led by ethnic Russians but includes Indigenous peoples who are employed in some municipalities, in addition to Indigenous representatives in the State Duma. Sakhalin's Regional Council of the Authorized Representatives of the Indigenous Minorities of the North, an organization established after the Green Wave campaign consisting of elected Indigenous representatives from different groups, represents Indigenous communities in negotiations and company consultations, but the organization is not 
involved in resource management. Over time the institutionalization of Indigenous organizations has deepened, in part due to grants from ENL and Sakhalin Energy. In Sakhalin, the availability of funding for Indigenous programs over the past decade has fostered Indigenous enterprises as well as their involvement in resource management. ${ }^{64}$ Compared to other parts of Russia, Sakhalin Indigenous peoples' organizations are now well-institutionalized and highly engaged in negotiations with both oil companies and governments, especially around benefit-sharing. ${ }^{65}$

\subsection{Indigenous Agency: Activism and Allies}

While ExxonMobil's implementation of corporate policies broadly follows a similar template with some adaptation to local institutions, there has been change over time in the company's approach to benefit-sharing - notably, a shift in programs in Sakhalin in the early 2000s. ${ }^{66}$ The development of ExxonMobil's benefit-sharing programs came in response to Indigenous activism and the model of Sakhalin Energy. An Indigenous-environmental grassroots campaign stretched from the sites of implementation to the global level, targeting the European Bank of Reconstruction and Development (EBRD), the investment bank which financed the Sakhalin-2 project, in order to put pressure on Sakhalin Energy, operator of the Sakhalin 2 project. The campaign was successful in that it contributed to a Sakhalin Indigenous Minorities Development Plan. The Plan, evaluted and renewed every five years, is designed to foster greater respect of Indigenous peoples' rights and allow them to participate in some aspects of benefit-sharing. These policy changes, as well as continued local Indigenous mobilization, later shaped ExxonMobil's engagement with Indigenous communities on Sakhalin and, according to interviewees, reverberated in Kaktovik, Alaska, encouraging fuller implementation of ExxonMobil's own governance commitments.

In Sakhalin, in response to Indigenous and environmental activism, ExxonMobil's approach to benefit-sharing shifted from one largely focused on compensation for damages to a more robust grant-based strategy with the involvement of Indigenous people in distributing resources to their communities and in monitoring impacts of the project's operations on the salmon population. In the period from 1999 to 2001, Russia's State Department of Environment and Natural Resources demanded compensation from ENL and the Sakhalin-1 project for damage to reindeer pastures, among other environmental impacts. ${ }^{67}$ Instead of formal compensation, the company voluntarily provided funds to reindeer herders in the Nogliki District to purchase supplies and improve local infrastructure ${ }^{68}$ In the following year, to protect the company from the regional government's persistent requests for compensation on behalf of Indigenous peoples, ENL devised an alternative approach. ${ }^{69}$ In 2002, ENL and the Association of Indigenous Peoples of Sakhalin Oblast jointly created an advisory committee for a grant program to provide funds to support cultural and social projects for Sakhalin's Indigenous population. ${ }^{70}$

At the same time, disruptions linked to extraction led to Indigenous mobilization. The Sakhalin-1 and Sakhalin-2 projects constructed pipelines that crossed more 
than 1,000 salmon spawning streams, causing concern among Indigenous people about salmon fishing, a traditional economic activity. ${ }^{71}$ Activists charged that ENL's contractors violated multiple environmental rules. ${ }^{72}$ The Green Wave campaign against oil development on Sakhalin emerged in 2005-2006 simultaneously at the site of implementation, where it was led by Indigenous activists, and through a transnational environmental NGO-led network pressuring the EBRD to review the projects, thereby creating a new forum of negotiation. In January 2005, several hundred Indigenous people from five Sakhalin districts, along with Sakhalin Environment Watch and several other environmental NGOs, demanded an ethnological impact assessment and compensation from the oil and gas consortia.

The campaign for greater consultation and transparency, as well as environmental protection, indirectly served to force a renegotiation of elements of ExxonMobil's diagram. Due to the nature of its financing, Sakhalin Energy, head of the Sakhalin-2 project, was more vulnerable to the Green Wave campaign than ENL. In January 2007, the EBRD canceled a USD $\$ 300$ million loan for Phase 2 of the Sakhalin-2 project due to violations of both Russian national legislation and global standards. ${ }^{73}$ ENL did not rely on international financial institutions as it was financed direclty by ExxonMobil. However, the Green Wave campaign influenced the benefit-sharing practices of both the Sakhalin-1 and Sakhalin-2 consortia. Under pressure from the regional government and the Association of Indigenous Peoples of Sakhalin Oblast, ENL adopted most of Sakhalin Energy's new benefit-sharing strategies following negotiations with the Regional Council of Authorized Representatives of the Indigenous Peoples of Sakhalin Oblast. ${ }^{74}$ In response to stakeholders' demands, in 2012 ENL again changed its grant program to more closely match the tripartite arrangement between Indigenous peoples' representatives, the Sakhalin regional government, and the company, created by Sakhalin Energy for the Sakhalin-2 project. ${ }^{75}$ This three-way agreement allowed more input for each party when distributing funds to Indigenous populations.

In this case, we see that over time ENL's minimalist approach to voluntary compensation for damages developed into a more multifaceted model of benefit-sharing. Indigenous activism, widespread praise for Sakhalin Energy's approach, and government pressure created incentives for ENL to develop a similar style of collaboration, such as formal procedures for grant applications and a greater role for Indigenous representatives in grant decision-making. Thus, implementation of global standards and corporate policies has evolved not only due to stakeholder resistance at the site of implementation, but in response to other actors in the GGN. This changing model has then gone on to influence benefit-sharing practices at other sites, including Kaktovik, near Point Thomson, in Alaska.

A decade later, similar aspects of this renegotiated diagram have been enacted in the TNC on the North Slope of Alaska, including the creation of the Kaktovik Community Foundation. An interviewee at ExxonMobil's headquarters claimed that lessons learned in Sakhalin were taken into account by the company in 
developing community relations in Point Thomson. ${ }^{76}$ In its corporate documents, Exxon emphasizes the TNC's sensitivity to Indigenous interests: "In the vicinity of our Point Thomson Project in northern Alaska, we work with the local communities and government authorities to understand their concerns and avoid conflicts with their traditional lifestyle. Through a comprehensive assessment and regular engagement, we have identified several areas of concern to the local people, and we have adopted corresponding measures to address these concerns." 77 At the time of our field work, ExxonMobil had not encountered significant community resistance, and interviewees expressed few grievances directly tied to the Point Thomson facility. Company representatives asserted that ExxonMobil cooperates with the NSB as well as the municipality and Indigenous peoples in Kaktovik on issues ranging from wildlife monitoring to cultural preservation. ${ }^{78}$

The role of environmental NGOs and their cooperation with Indigenous communities on Sakhalin Island and Alaska's North Slope also differ across the two cases, however. In Sakhalin, environmental NGOs supported Indigenous rights during the Green Wave campaign, alongside a global campaign to preserve Western Pacific grey whales. This Indigenous-environmental alliance in Sakhalin has weakened over time. With the exception of the 1989 Exxon Valdez oil spill in Alaska's Prince William Sound, ${ }^{79}$ ExxonMobil's operations in Alaska have not elicited the level of Indigenous and environmental protests that occurred during the Green Wave movement on Sakhalin. While Kaktovik residents express greater on-going concern about harm to marine mammals and other wildlife, Alaska Natives from the North Slope generally do not cooperate with environmental NGOs, in part due to past NGO campaigns against seal and whale hunting, and tend to have an adversarial relationship with federal wildlife agencies, with some interviewees expressing the sentiment that these are colonizing institutions that negatively intervene in Indigenous stewardship and management of natural resources.

\section{Conclusion}

In this study, we examine how a TNC in the extractives sector that operates in multiple geographical settings develops a standard diagram of policies which is then adapted to local contexts. Similarity in TNC policies and programs is a product of global standards, CSR policies, and the TNC's desire to lower transaction costs and minimize risk. Specifically we investigate how ExxonMobil develops its corporate policies, partly in response to global standards, to construct a diagram - or standardized approach - to engaging Indigenous peoples at sites of implementation, in part to avoid reputational damage associated with Indigenous protests. The TNC attempts to replicate its approach to engagement with Indigenous peoples in strikingly different contexts at sites of implementation by using specialized teams who work globally to launch new extractive projects. At the center of this diagram are benefit-sharing programs. 
However, this diagram must adapt to pre-existing institutional arrangements at the site of implementation and is subject to renegotiation, leading to variation. Even as TNCs develop relatively universal approaches toward Indigenous communities that can be applied in different socio-economic contexts, local conditions influence practices of benefit-sharing and community engagement at different sites of implementation, including pre-existing Indigenous self-government institutions, varied resource ownership models, and different roles for government agencies. Indigenous movements and associations and the policies of other corporate actors may play important roles in shaping how corporate policies and global standards are implemented at sites of extraction.

Notably, actors such as Indigenous associations and social movements play a crucial role in negotiating, resisting, or adapting to corporate policies. By engaging in resistance, such as protests, Indigenous peoples promote new practices of benefit-sharing. ${ }^{80}$ In the case of ENL in Sakhalin, we show how an Indigenous and environmental campaign can prompt the revision of the TNC's diagram, forcing new strategies and programs to implement corporate commitments in communities proximate to extraction - changes to the diagram that were then disseminated to other sites. In Alaska, greater opportunities for Indigenous leadership at the borough, city, and village level may ensure more opportunites for Indigenous voices in governance, beyond Indigenous associations, although this remains an open question.

Thus, even as these case studies illustrate how ExxonMobil has developed a diagram of benefit-sharing with Indigenous communities, we also see that a TNC's efforts to develop universal strategies to manage risk and avoid reputational damage must be continuously adapted in response both to institutional specificities in local sites of extraction and to Indigenous resistance to social and environmental damage resulting from extraction. The company's approach to engaging Indigenous communities is likely to continue to develop and change following efforts to further entrench Indigenous rights and self-governance, both internationally and in specific countries. In this continually evolving context, the respective roles of TNCs and Indigenous communities in negotiating benefit-sharing and environmental protection continues to offer a dynamic and significant issue for further research.

\section{Acknowledgments}

This research was supported by the NWO, the Netherlands Organization for Scientific Research, Arctic Program ('Developing benefit sharing standards in the Arctic', No. 866.15.203); the National Council for Eurasian and East European Research ('National Interests and Transnational Governance: Russia's Changing Environmental Policy', No. 827-06); and Kone Foundation (Diversities of the Environmental Movement in Russia, No 202005986). 


\section{NOTES}

1. Braun, Boris. "Building global institutions: the diffusion of management standards in the world economy-an institutional perspective." In Linking industries across the world, pp. 3-28. Oxford: Routledge, 2019; Kolk, Ans, Rob Van Tulder, and Carlijn Welters. "International codes of conduct and corporate social responsibility: can transnational corporations regulate themselves?" Transnational corporations 8, no. 1 (1999): 143-180.

2. Seid, Sherif H. Global regulation of foreign direct investment. Routledge, 2018; Turner, Mandy. "Taming mammon: corporate social responsibility and the global regulation of conflict trade." Conflict, Security \& Development 6, no. 3 (2006): 365-387.

3. O'Faircheallaigh, Ciaran, and Saleem Ali, eds. Earth matters: Indigenous peoples, the extractive industries and corporate social responsibility. Routledge, 2017.

4. Thuy, Pham Thu, Maria Brockhaus, Grace Wong, Januarti Sinarra Tjajadi, Lasse Loft, Cecilia Luttrell, and Samuel Assemble Mvondo. Approaches to benefit sharing: A preliminary comparative analysis of 13 REDD+ countries. Vol. 108. CIFOR, 2013.

5. Southcott, Chris, and David Natcher. "Extractive industries and Indigenous subsistence economies: A complex and unresolved relationship." Canadian fournal of Development Studies/Revue canadienne d'études du développement 39, no. 1 (2018): 137-154; Petrov, Andrey N., and Maria S. Tysiachniouk. "Benefit sharing in the arctic: A systematic view." Resources 8, no. 3 (2019): 155.

6. Deleuze, G. Foucault. Minneapolis: University of Minnesota Press, 1995.

7. See O'Faircheallaigh and Ali, 2017

8. Sulyandziga, Liubov. "Indigenous Peoples and Extractive Industry Encounters: BenefitSharing Agreements in Russian Arctic.” Polar Science 21 (June 2018) 2019: 68-74. Horowitz, Leah S., Arn Keeling, Francis Lévesque, Thierry Rodon, Stephan Schott, and Sophie Thériault. "Indigenous peoples' relationships to large-scale mining in post/colonial contexts: Toward multidisciplinary comparative perspectives." The Extractive Industries and Society 5, no. 3 (2018): 404-414.

9. Du, Shuili, and Edward T.Vieira. "Striving for legitimacy through corporate social responsibility: Insights from oil companies.” fournal of business ethics 110, no. 4 (2012): 413-427.

10. See Tysiachniouk et al., 2018.

11. Tysiachniouk, Maria S. Transnational governance through private authority: The case of Forest Stewardship Council certification in Russia. Vol. 7. Wageningen Academic Publishers, 2012.

12. Tysiachniouk, Maria, Laura A. Henry, Machiel Lamers, and Jan PM van Tatenhove. "Oil and Indigenous people in sub-Arctic Russia: Rethinking equity and governance in benefit sharing agreements." Energy Research $\mathcal{E}$ Social Science 37 (2018): 140-152; Tulaeva, Svetlana A., Maria S. Tysiachniouk, Laura A. Henry, and Leah S. Horowitz. "Globalizing extraction and Indigenous rights in the Russian Arctic: The enduring role of the state in natural resource governance." Resources 8, no. 4 (2019): 179.

13. Deleuze, G. Foucault. Minneapolis: University of Minnesota Press.1995, p. 36.

14. De Landa, Manuel. "Deleuze, diagrams, and the genesis of form." Amerikastudien/American Studies (2000): 33-41.

15. Dressler, Wolfram, Bram Büscher, Michael Schoon, D. A. N. Brockington, Tanya Hayes, Christian A. Kull, James McCarthy, and Krishna Shrestha. "From hope to crisis and back again? A critical history of the global CBNRM narrative." Environmental conservation 37, no. 1 (2010): 5-15; Horowitz, Leah S. "Rhizomic resistance meets arborescent assemblage: UNESCO World Heritage and the disempowerment of Indigenous activism in New Caledonia." Annals of the American Association of Geographers 106, no. 1 (2016): 167-185; Zdebik, Jakub. Deleuze and the diagram: Aesthetic threads in visual organization. Bloomsbury Publishing, 2012.

16. Yeung, Henry Wai-Chung. "Transnational corporations, global production networks, and urban and regional development: A geographer's perspective on Multinational enterprises and the global economy." Growth and Change 40, no. 2 (2009): 197-226. 


\section{Maria S. Tysiachniouk, Laura A. Henry and Leah S. Horowitz}

17. Fligstein, Neil, and Doug McAdam. A theory of fields. Oxford: Oxford University Press. (2012), see p. 29; see also Tysiachniouk 2012.

18. Petrov, Andrey N., and Maria S. Tysiachniouk. "Benefit sharing in the arctic: A systematic view." Resources 8, no. 3 (2019): 155.

19. Grantham, Susan, and Edward T. Vieira Jr. "ExxonMobil's social responsibility messaging-2002-2013 CEO letters." Applied Environmental Education E Communication 17, no. 3 (2018): 266-279.

20. Coll, Steve. Private empire: ExxonMobil and American power. Penguin, 2012; ExxonMobil. (2018). Worldwide giving. Accessed March 9, 2020. Available online at: https://corporate. exxonmobil.com/Community-engagement/Worldwide-giving; Mbat et al., 2013, Ibok and Mboho, 2011; Shah, Naman K. "Corporate philanthropy and conflicts of interest in public health: ExxonMobil, Equatorial Guinea, and malaria." Fournal of public health policy 34; no. 1 (2013): 121-136; Zawada, Anna. "Neoliberal Governmentality, Corporate Responsibility, and the Governing of Citizens in Nigeria: The case of ExxonMobil, Shell, and Chevron." (2010); Michael, Ibe Chidi, Wang Zhi Min, Kwek Choon Ling, and Daniel Yii Shiing Kai. "Proposition of an interactive process approach in exploring the relationship between corporate social responsibility (CSR) strategy and perceived CSR: Case of ExxonMobil in Nigeria's petroleum industry." International fournal of Business and Management 10, no. 2 (2015): 186; Dikeocha, Chijioke. "Corporate Social Responsibility Reporting in the Online News Letters of ExxonMobil and SPDC in Nigeria.” International Fournal of Sustainable Entrepreneurship and Corporate Social Responsibility (IFSECSR) 4, no. 1 (2019): 27-41.

21. Livesey, Sharon M. "Global warming wars: Rhetorical and discourse analytic approaches to ExxonMobil's corporate public discourse." The fournal of Business Communication (1973) 39, no. 1 (2002): 117-146; Horta, Korinna. "Public-Private Partnership and Institutional Capture: The State, International Institutions, and Indigenous Peoples in Chad and Cameroon.” In The Politics of Resource Extraction, pp. 204-229. Palgrave Macmillan, London, 2012; Coupland, Christine. "Corporate social responsibility as argument on the web." fournal of business ethics 62, no. 4 (2005): 355-366.

22. ExxonMobil "Indigenous peoples." 2018c Accessed on: March 6, 2020. Available online at: https://corporate.exxonmobil.com/Community-engagement/Working-with-communities/ Indigenous-peoples

23. ExxonMobil. "Indigenous peoples." 2018 Accessed on: March 6, 2020. Available online at: https://corporate.exxonmobil.com/Community-engagement/Working-with-communities/ Indigenous-peoples

24. Woods, David. W. "Standards of Business Conduct: ExxonMobil”, 2017 Accessed March 6, 2020. Available online at: https://corporate.exxonmobil.com/Community-engagement/ Sustainability-Report/Social/Human-Rights\#respectingHumanRights

25. Novikova, Natalia \& Wilson, Emma. "The Sakhalin-2 project grievance mechanism." Dispute or Dialogue: Community Perspectives on Company-Led Grievance Mechanisms, 84-109, 2013, see p. 84.

26. Bradshaw, Mike. "The 'greening 'of global project financing: the case of the Sakhalin-II offshore oil and gas project.” The Canadian Geographer/Le Géographe canadien 51, no. 3 (2007): 255-279.

27. Bradshaw, Michael. "A new energy age in Pacific Russia: Lessons from the Sakhalin oil and gas projects.” Eurasian Geography and Economics 51, no. 3 (2010): 330-359.

28. In 2022, Hillcorp, which purchased BP's stake in Point Thomson in 2020, will take over from ExxonMobil as operator of Point Thomson (Liz Ruskin, "Exxon transfers Point Thomson operations on Alaska's North Slope to Hilcorp," Alaska Public Media, October 21, 2021, https:// www.alaskapublic.org/2021/10/22/exxon-transfers-point-thomson-operations-to-hilcorp/).

29. ExxonMobil “About ExxonMobil Alaska," 2018, September 26, https://corporate.exxonmobil.com/Locations/United-States/Alaska/About-ExxonMobil-Alaska\#WhatWeDo, accessed 04.05.2020 


\section{Global Standards, Corporate Diagrams and Indigenous Agency}

30. ExxonMobil "ExxonMobil's Point Thomson reservoir", 2018 Accessed March 9, 2020. Available online at: https:/corporate.exxonmobil.com/Locations/United-States/Alaska/ ExxonMobil-Point-ThomsonThomson-reservoir

31. See Brehmer 2019.

32. Miller, Lauren B., Jeffrey C. Hallo, Robert G. Dvorak, Jessica P. Fefer, Brian A. Peterson, and Matthew TJ Brownlee. "On the edge of the world: Examining pro-environmental outcomes of last chance tourism in Kaktovik, Alaska." fournal of Sustainable Tourism 28, no. 11 (2020): 1703-1722.

33. Kentch, Gavin. "A Corporate Culture-The Environmental Justice Challenges of the Alaska Native Claims Settlement Act.” Miss. Lf 81 (2011): 813.

34. See Miller et.al 2020.

35. See Tysiachniouk et al 2018.

36. Tysiachniouk, Maria S. "Disentangling Benefit-Sharing Complexities of Oil Extraction on the North Slope of Alaska." Sustainability 12, no. 13 (2020): 5432.

37. North Slope Borough “Comprehensive Plan," 2019 http://www.north-slope.org/assets/images/ uploads/NSB_Comprehensive_Plan_2019-2039_Reduced.pdf, accessed 20.12.2020.

38. Interview with Kaktovik municipal staff person, 16.06.2016; interview with ExxonMobil Point Thomson Project Community Relations Lead, Fairbanks, 29.09.2015.

39. Sakhalin-1 “Contributions”, May 2, 2019a, https://www.sakhalin-1.com/en-RU/Socialresponsibility/Community-and-society/Contributions, accessed 13.04.2020.

40. See Tysiachniouk et.al 2018.

41. Interview with the Head of administration, Okha; ENL PR manager of administration, Okha, 17.08.2015.

42. Tsoi M., vice president of "Exxon Neftegas Limited," a record of the conference «Indigenous nations and industrial companies: cooperation, outlooks, challenges," 10.2013.

43. ENL. Exxon Neftegas Limited Announces Winners of the Social Grant Projects Competition, 28 January 2020, https://www.sakhalin-1.com/en-RU/Media-room/Newsroom/ News-releases/2020/0129_ENL-Social-Grants-Projects-Winners, accessed 13.04.2020).

44. Interview with community investment advisor for ExxonMobil in Alaska 16.10.2015.

45. Scruggs, George "Oil giant backs high-tech rescue for collapsing Arctic ice cellars", 2019. Accessed on March 11, 2020. Available online at: https://www.reuters.com/article/us-arctic-climatechange-food-feature/oil-giant-backs-high-tech-rescue-for-collapsing-arctic-ice-cellars-idUSKCN1PN1Q5

46. Interview with Kaktovik mayor and municipal staff person 16.06.2016.

47. Interview with tribal government representative 17.06.2016.

48. Interview with ExxonMobil Point Thomson Project Community Relations Lead, Fairbanks, 29.09.2015.

49. Interview with municipal staff person 16.06.2016.

50. Interview with municipal staff person 16.06.2016.

51. Interview with Community Relations Advisor 29.09.2015.

52. Febbo, E., C. Wooley, J. Rogers, J. Reuther, and B. Reep. "A novel approach to cultural resource management: Historical artifacts and reciprocal mitigation." In SPE Health, Safety, Security, Environment, E Social Responsibility Conference-North America. OnePetro, 2017. Society of Petroleum Engineers. https://www.onepetro.org/conference-paper/SPE184427-MS, accessed 12.05.2020

53. Interview with Community Relations Advisor 29.09.2015.

54. Sakhalin-1. (2019b) Biodiversity Conservation Program of Exxon Neftegas Limited, https:// www.sakhalin-1.com/-/media/Sakhalin/Files/Environment-and-safety/Public-consultationsand-assessments/ENG/Environment-ratings/ENL-Biodiversity-Conservation-Program.pdf, accessed 14.04.2020). 


\section{Maria S. Tysiachniouk, Laura A. Henry and Leah S. Horowitz}

55. Novikova Natalia. "Energy of entrepreneurship in traditional nature use of indigenous peoples of the Sakhalin North." Izvestiya Laboratorii drevnikh tekhnologii (Reports of the Laboratory of Ancient Technologies_.Vol. 16. No. 3. P. (2020): 127-140.

56. Interview with community investment advisor for ExxonMobil in Alaska, 16.10.2015.

57. Interview with former employee of ExxonMobil Government relations office 01.02.2018.

58. Interview with ExxonMobil Corporation Public and Government Affairs, Community Relations Advisor.

59. Wilson, Emma. "Freedom and loss in a human landscape: multinational oil exploitation and the survival of reindeer herding in north-eastern Sakhalin, the Russian Far East." Sibirica 3, no. 1 (2003): 21-47.

60. See Tysiachniouk et al. 2018.

61. Hull, Teresa, and Linda E. Leask. Dividing Alaska, 1867-2000: changing land ownership and management. University of Alaska Anchorage, Institute of Social and Economic Research, 2000.

62. The Arctic Slope Regional Corporation (ASRC) decided to distribute shares to those born after 1972, while Kaktovik Inupiat Corporation does not.

63. See Alaska News "ASRC announces quarterly dividend distribution", $2021 \mathrm{http}: / / \mathrm{www}$. newsminer.com/news/alaska_news/asrc-announces-quarterly-dividend-distributions/, accessed 02.02.2021.

64. See Tysiachniouk et al 2018.

65. Wilson, Emma. "What is the social licence to operate? Local perceptions of oil and gas projects in Russia's Komi Republic and Sakhalin Island." The Extractive Industries and Society 3, no. 1 (2016): 73-81.

66. ExxonMobil "Code of ethics". Accessed March 6, 2020. Available online at: https://corporate.exxonmobil.com/Company/Who-we-are/Corporate-governance/Code-of-ethics\# codeOfEthicsAndBusinessConduct

67. Interview with PR coordinator of Exxon Neftegas Limited, Yuzhno-Sakhalinsk, 14.08.2015.

68. See Roon, 2006.

69. Interview with PR coordinator of Exxon Neftegas Limited, Yuzhno-Sakhalinsk, 14.08.2015.

70. See Tysiachniouk et.al 2018.

71. See Bradshaw 2007 and Bradshaw 2010.

72. Graybill, Jessica K. "Mapping an emotional topography of an ecological homeland: The case of Sakhalin Island, Russia." Emotion, Space and Society 8 (2013): 39-50.

73. See Bradshaw 2007.

74. Roon, Tatiana. "Globalization of Sakhalin's Oil Industry: Partnership or Conflict? A Reflection on the Etnologicheskaia Ekspertiza." Sibirica 5, no. 2 (2006): 95-114, see p. 107.

75. See Tysiachniouk et al. 2018.

76. Interview with ExxonMobil Corporation staff person, 01.02.2018.

77. ExxonMobil, 2018c; ExxonMobil "Operations integrity management system." 2018b, Accessed on: March 6, 2020. Available online at: https://corporate.exxonmobil.com/ Energy-and-environment/Tools-and-processes/Risk-management-and-safety/OperationsIntegrity-Management-System

78. Schmidt, R. Point Thomson Project's Alaska North Slope Borough Community Engagement Program. In SPE International Conference on Health, Safety, and Environment. Society of Petroleum Engineers, 2014.

79. Birkland, Thomas A., and Regina G. Lawrence. "The social and political meaning of the Exxon Valdez oil spill.” Spill Science Eo Technology Bulletin 7, no. 1-2 (2002): 17-22.

80. Bartley, Tim. "How foundations shape social movements: The construction of an organizational field and the rise of forest certification." Social problems 54, no. 3 (2007): 229-255; Powell, Walter W., Douglas R. White, Kenneth W. Koput, and Jason Owen-Smith. "Network dynamics and field evolution: The growth of interorganizational collaboration in the life sciences." American journal of sociology 110, no. 4 (2005): 1132-1205. 


\section{Appendix A}

Table 1. List of interviews in Alaska

\begin{tabular}{|c|c|c|c|c|}
\hline Date & Place & Category & Interviews & Number \\
\hline 14.10 .2015 & Anchorage & Indigenous & $\begin{array}{l}\text { President of AFN } \\
\text { Alaska Area Vise President, National } \\
\text { Congress of American Indians }\end{array}$ & 1 \\
\hline 14.10 .2015 & Anchorage & Government & $\begin{array}{l}\text { Commissioner, Alaska Department of } \\
\text { Revenue }\end{array}$ & 1 \\
\hline 16.10 .2015 & Anchorage & Company & $\begin{array}{l}\text { Community investment advisor for } \\
\text { ExxonMobil in Alaska }\end{array}$ & 1 \\
\hline 14.10 .2015 & Anchorage & Indigenous tribe & President, Tanana Chiefs Conference & 1 \\
\hline 14.10 .2015 & Anchorage & Indigenous tribe & Tribal Member, Gulkana village Council & 1 \\
\hline 14.10 .2015 & Anchorage & $\begin{array}{l}\text { Federally } \\
\text { Recognized } \\
\text { Regional Tribal } \\
\text { government }\end{array}$ & $\begin{array}{l}\text { Vice president } \\
\text { Inupiat Community of the Arctic Slope }\end{array}$ & 1 \\
\hline 17.10 .2015 & Anchorage & $\begin{array}{l}\text { Federal } \\
\text { government }\end{array}$ & $\begin{array}{l}\text { Sr. Advisor, Communication Strategy } \\
\text { and Engagement Chair Sustainable } \\
\text { Development Working Group }\end{array}$ & 1 \\
\hline 16.10 .2015 & Anchorage & Company & BP, Director of Community Affairs & 1 \\
\hline 16.10 .2015 & Anchorage & Company & $\begin{array}{l}\text { Community investment advisor for } \\
\text { ExxonMobil in Alaska }\end{array}$ & 1 \\
\hline 24.09 .2015 & Fairbanks & Company & $\begin{array}{l}\text { Statoil Alaska Regulatory Compliance } \\
\text { Manager }\end{array}$ & 1 \\
\hline 29.09 .2015 & Fairbanks & Oil company & $\begin{array}{l}\text { Wildlife and Community Relations } \\
\text { Supervisor, ExxonMobil }\end{array}$ & 1 \\
\hline $\begin{array}{l}28.09 .2015 \\
29.09 .2015\end{array}$ & Fairbanks & Oil company & $\begin{array}{l}\text { ExxonMobil } \\
\text { Point Towson Project Community } \\
\text { Relations Lead }\end{array}$ & 2 \\
\hline 29.09 .2015 & Fairbanks & Oil company & $\begin{array}{l}\text { ExxonMobil Corporation Public and } \\
\text { Government Affairs, Community } \\
\text { Relations Advisor }\end{array}$ & 1 \\
\hline 29.09 .2015 & Fairbanks & Oil company & $\begin{array}{l}\text { ExxonMobil Development Company } \\
\text { SSH@E Manager, Point Towson }\end{array}$ & 1 \\
\hline $\begin{array}{l}29.09 .2015 \\
30.09 .2015\end{array}$ & Fairbanks & Oil company & ExxonMobil Huston Office & \\
\hline 04.06 .2016 & Utqiagvik & $\begin{array}{l}\text { Indigenous } \\
\text { leader }\end{array}$ & $\begin{array}{l}\text { vice president of the Inupiat Community } \\
\text { of the Arctic Slope, former Mayor of the } \\
\text { North Slope Borough, running for the } \\
\text { Mayor in } 2016\end{array}$ & 1 \\
\hline 03.06 .2016 & Utqiagvik & NSB & $\begin{array}{l}\text { North Slope Borough Planning } \\
\text { Department, member of SAP panel }\end{array}$ & 1 \\
\hline 30.05 .2016 & Utqiagvik & Government & $\begin{array}{l}\text { Administrative Manager of whaling } \\
\text { commission }\end{array}$ & 1 \\
\hline 30.05 .2016 & Utqiagvik & Government & $\begin{array}{l}\text { Alaska Eskimo Whaling Commission } \\
\text { Executive Director }\end{array}$ & 1 \\
\hline
\end{tabular}


Table 1. (Continued)

\begin{tabular}{|c|c|c|c|c|}
\hline Date & Place & Category & Interviews & Number \\
\hline 06.06 .2016 & Utqiagvik & $\begin{array}{l}\text { Native } \\
\text { corporation }\end{array}$ & $\begin{array}{l}\text { Arctic Slope Regional Corporation, } \\
\text { shareholder community program }\end{array}$ & 1 \\
\hline 20.06 .2016 & Utqiagvik & Tribe & $\begin{array}{l}\text { Inupiat Community of the Arctic Slope } \\
\text { (ICAS-acting director) }\end{array}$ & 1 \\
\hline 20.06 .2016 & Utqiagvik & Tribe & $\begin{array}{l}\text { Inupiat Community of the Arctic Slope } \\
\text { Natural Resource Director }\end{array}$ & 1 \\
\hline 20.06 .2016 & Utqiagvik & Tribe & $\begin{array}{l}\text { Native Village of Utqiagvik } \\
\text { Executive director }\end{array}$ & 1 \\
\hline 20.06.2016 & Utqiagvik & $\begin{array}{l}\text { Indigenous } \\
\text { resident }\end{array}$ & whaler & 1 \\
\hline 17.06 .2016 & Utqiagvik & $\begin{array}{l}\text { Native } \\
\text { corporation }\end{array}$ & $\begin{array}{l}\text { Wainwright Village Operations - } \\
\text { Olgoonik, } \\
\text { Financial director }\end{array}$ & 1 \\
\hline 21.06 .2016 & Utqiagvik & NSB & NSB Department of Natural Resources & 1 \\
\hline 20.06.2016 & Utqiagvik & $\begin{array}{l}\text { Native } \\
\text { corporation }\end{array}$ & ASRC, shareholder department & 1 \\
\hline $13.06,2016$ & Kaktovik & tribe & Native village of Kaktovik & 1 \\
\hline $\begin{array}{l}14.06,2016 \\
15.06 .2016\end{array}$ & Kaktovik & Local residents & Tour guides & 2 \\
\hline 16.06 .2016 & Kaktovik & municipality & municipality staff person & 1 \\
\hline 16.06 .2016 & Kaktovik & Local resident & Post office & 1 \\
\hline 01.09 .2017 & $\begin{array}{l}\text { Anchorage } \\
\text { (interview took } \\
\text { place in Kaktovik }\end{array}$ & $\begin{array}{l}\text { Nonprofit Law } \\
\text { firm }\end{array}$ & $\begin{array}{l}\text { Trustees for Alaska, executive director, } \\
\text { staff }\end{array}$ & 3 \\
\hline 30.08 .2017 & Kaktovik & $\begin{array}{l}\text { Federal } \\
\text { government } \\
\text { agency }\end{array}$ & ANWAR representative in Kaktovik & 1 \\
\hline 02.09 .2017 & Kaktovik & Local resident & School teacher & 1 \\
\hline 04.09 .2017 & Utqiagvik & Local resident & Artist, wailer & 1 \\
\hline 04.09 .2017 & Utqiagvik & Local resident & Elders & 2 \\
\hline 04.09 .2017 & Utqiagvik & Local resident & Land owner & 1 \\
\hline $\begin{array}{l}03.09 .2017 \\
01.09 .2017\end{array}$ & Kaktovik & Local resident & Tour guides & 3 \\
\hline 04.09 .2017 & Kaktovick & $\begin{array}{l}\text { Indigenous } \\
\text { resident }\end{array}$ & Tourist guide, bed and breakfast worker & 2 \\
\hline 01.09 .2017 & Kaktovik & Local resident & City administrator & 1 \\
\hline 09.09 .2017 & Anchorage & Oil company & ConocoPhillips representative & 1 \\
\hline 03.09 .2017 & Kaktovik & Business & Waldorf hotel owner and his wife & 2 \\
\hline 04.09 .2017 & Utqiagvik & Business & $\begin{array}{l}\text { Bed and breakfast owner, previously } \\
\text { worked at NSB }\end{array}$ & 1 \\
\hline 05.09 .2017 & Utqiagvik & $\begin{array}{l}\text { Indigenous } \\
\text { leader }\end{array}$ & Candidate for NSB Mayor & 1 \\
\hline 08.09 .2017 & Anchorage & Expert & $\begin{array}{l}\text { Executive director of the Institute of the } \\
\text { North }\end{array}$ & 1 \\
\hline
\end{tabular}


Global Standards, Corporate Diagrams and Indigenous Agency

\begin{tabular}{llllc}
\hline Date & Place & Category & Interviews & Number \\
\hline 18.01 .2017 & Houston & Oil company & $\begin{array}{l}\text { Representative of oil exploration } \\
\text { company, ExxonMobil } \\
\text { (written input) }\end{array}$ & 1 \\
\hline 19.01 .2018 & Houston & Oil company & $\begin{array}{l}\text { ConocoPhillips, Director, Stakeholder } \\
\text { Engagement \& Social Responsibility }\end{array}$ & 1 \\
\hline 01.02 .2018 & Houston & Oil Company & $\begin{array}{l}\text { Representative of PetroNeft Resources, } \\
\text { worked for Schell }\end{array}$ & 1 \\
\hline 01.02 .2018 & Houston & Oil Company & $\begin{array}{l}\text { Former employee of ExxonMobil } \\
\text { government relations office }\end{array}$ & 1 \\
\hline 23.01 .2018 & Houston & Oil Company & Former public relations officer at Shell & 1 \\
\hline 17.07 .2018 & Utqiagvik & $\begin{array}{l}\text { Regional } \\
\text { Corporation }\end{array}$ & Spokesmen for ASRC & 1 \\
\hline 18.07 .2018 & Utqiagvik & $\begin{array}{l}\text { Regional } \\
\text { Corporation }\end{array}$ & $\begin{array}{l}\text { Resource and Development officer, } \\
\text { ASRC }\end{array}$ & 1 \\
\hline 18.07 .2018 & Utqiagvik & $\begin{array}{l}\text { Regional } \\
\text { Corporation }\end{array}$ & ASRC President & 1 \\
\hline 19.07 .2018 & Nuiqsut & $\begin{array}{l}\text { Municipal } \\
\text { government }\end{array}$ & Representative of Mayor's office & 1 \\
\hline 22.07 .2018 & Nuiqsut & $\begin{array}{l}\text { Tribal } \\
\text { government }\end{array}$ & Vise president & 1 \\
\hline 22.07 .2018 & Nuiqut & $\begin{array}{l}\text { Tribal } \\
\text { government }\end{array}$ & Representative of Native Village of \\
\hline 23.07 .2018 & Nuiqsut & $\begin{array}{l}\text { Indigenous } \\
\text { resident }\end{array}$ & Subsistence hunter & 1 \\
\hline 29.07 .2018 & Denali Village & $\begin{array}{l}\text { Municipal } \\
\text { Government }\end{array}$ & Nuiqsut City administrator & 1 \\
\hline 04.08 .2018 & Anchorage & Oil Company & Public outreach officer & 1 \\
\hline & & & & 1 \\
\hline
\end{tabular}




\section{Appendix B}

Table 2. List of interviews on Sakhalin Island

\begin{tabular}{|c|c|c|c|c|}
\hline Dates of travel & $\begin{array}{l}\text { Place of } \\
\text { interview }\end{array}$ & $\begin{array}{l}\text { Professional } \\
\text { affiliation }\end{array}$ & $\begin{array}{l}\text { position } \\
\text { date of the interview }\end{array}$ & $\begin{array}{l}\text { Number of } \\
\text { interviews }\end{array}$ \\
\hline August 2015 & Yuzno Sakhalinsk & $\begin{array}{l}\text { Sakhalin State } \\
\text { University, } \\
\text { Sakhalin Energy, } \\
\text { expert }\end{array}$ & $\begin{array}{l}\text { Professor } \\
\text { Head of social impact } \\
\text { assessment team of } \\
\text { Sakhalin } \\
08.08 .2015\end{array}$ & 1 \\
\hline $\begin{array}{l}\text { August } 2015 \\
\text { September } 2013\end{array}$ & $\begin{array}{l}\text { Village } \\
\text { Nekrasovka }\end{array}$ & $\begin{array}{l}\text { Center for the } \\
\text { preservation and } \\
\text { development of } \\
\text { traditional culture of } \\
\text { Indigenous peoples' } \\
\text { Kyhkyh "("Swan"), } \\
\text { The Regional Board } \\
\text { of Authorized } \\
\text { representatives } \\
\text { (Commissioners) of } \\
\text { Indigenous peoples of } \\
\text { Sakhalin region. }\end{array}$ & $\begin{array}{l}\text { Chairman } \\
10.08 .2015,09.2013\end{array}$ & 2 \\
\hline $\begin{array}{l}\text { August } 2015 \\
\text { September } 2013\end{array}$ & $\begin{array}{l}\text { Village } \\
\text { Nekrasovka }\end{array}$ & $\begin{array}{l}\text { "Exxon Neftegas } \\
\text { Limited" } \\
\text { Center for the } \\
\text { preservation and } \\
\text { development of } \\
\text { traditional culture of } \\
\text { Indigenous peoples' } \\
\text { Kyhkyh "("Swan") }\end{array}$ & $\begin{array}{l}\text { Public relations } \\
\text { representative for } \\
\text { "Exxon Neftegas } \\
\text { Limited" } \\
\text { Kyhkyh staff person } \\
10.08 .2015,09.2013\end{array}$ & 2 \\
\hline August 2015 & Poronaisk & $\begin{array}{l}\text { The Regional Board } \\
\text { of Authorized } \\
\text { representatives } \\
\text { (Commissioners) of } \\
\text { Indigenous peoples of } \\
\text { Sakhalin region. }\end{array}$ & $\begin{array}{l}\text { Representative, } \\
10.08 .2015\end{array}$ & 1 \\
\hline August 2015 & Yuzno Sakhalinsk & $\begin{array}{l}\text { "Exxon Neftegas } \\
\text { Limited" }\end{array}$ & $\begin{array}{l}\text { Director on public } \\
\text { relations, } 11.08 .2015\end{array}$ & $\begin{array}{l}1 \\
2\end{array}$ \\
\hline $\begin{array}{l}\text { August } 2015 \\
\text { September } 2013\end{array}$ & & & $\begin{array}{r}\text { Public Relations staff } \\
11.08 .2015,09.2013\end{array}$ & \\
\hline $\begin{array}{l}\text { August } 2015 \\
\text { September } 2013\end{array}$ & Yuzno Sakhalinsk & $\begin{array}{l}\text { State Department of } \\
\text { Indigenous Minorities } \\
\text { of the North }\end{array}$ & $\begin{array}{l}\text { Vice chair, } \\
11.08 .2015, \\
09.2013\end{array}$ & 2 \\
\hline August 2015 & Yuzno Sakhalinsk & «Sakhalin Energy» & $\begin{array}{l}\text { Public Relations } \\
\text { manager, 12.08.2015 }\end{array}$ & 1 \\
\hline August 2015 & Yuzno Sakhalinsk & $\begin{array}{l}\text { Rosprirodnadzor of } \\
\text { Sakhalin oblast }\end{array}$ & $\begin{array}{l}\text { Head, } \\
13.08 .2015\end{array}$ & 1 \\
\hline August 2015 & Poronaisk & $\begin{array}{l}\text { Council of Regional } \\
\text { Representatives of } \\
\text { Indigenous people }\end{array}$ & $\begin{array}{l}\text { member, } \\
14.08 .2015\end{array}$ & 1 \\
\hline
\end{tabular}




\begin{tabular}{|c|c|c|c|c|}
\hline Dates of travel & $\begin{array}{l}\text { Place of } \\
\text { interview }\end{array}$ & $\begin{array}{l}\text { Professional } \\
\text { affiliation }\end{array}$ & $\begin{array}{l}\text { position } \\
\text { date of the interview }\end{array}$ & $\begin{array}{l}\text { Number of } \\
\text { interviews }\end{array}$ \\
\hline \multirow[t]{2}{*}{ August 2015} & Okha & $\begin{array}{l}\text { Okha city } \\
\text { administration }\end{array}$ & Head, & 1 \\
\hline & & & $\begin{array}{l}\text { Specialist on public } \\
\text { relations, } 17.08 .2015\end{array}$ & 1 \\
\hline August 2015 & Okha & $\begin{array}{l}\text { "Exxon Neftegas } \\
\text { Limited" }\end{array}$ & $\begin{array}{l}\text { Okha company } \\
\text { representative, } \\
17.08 .2015\end{array}$ & 1 \\
\hline $\begin{array}{l}\text { August } 2015 \\
\text { September } 2013\end{array}$ & $\begin{array}{l}\text { Village } \\
\text { Nekrasovka }\end{array}$ & & $\begin{array}{l}\text { Local activist, } \\
18.08 .2015,09.2013\end{array}$ & 2 \\
\hline $\begin{array}{l}\text { August } 2015 \\
\text { September } 2013\end{array}$ & $\begin{array}{l}\text { Village } \\
\text { Nekrasovka }\end{array}$ & & $\begin{array}{l}\text { Local fishemen, } \\
18.05 .2015,09.2013\end{array}$ & 2 \\
\hline August 2015 & $\begin{array}{l}\text { Village } \\
\text { Nekrasovka }\end{array}$ & Local administration & $\begin{array}{l}\text { Head, } \\
18.05 .2015\end{array}$ & 1 \\
\hline August 2015 & $\begin{array}{l}\text { Village } \\
\text { Nekrasovka }\end{array}$ & & $\begin{array}{l}\text { Local resident, } \\
19.08 .2015\end{array}$ & 1 \\
\hline August 2015 & $\begin{array}{l}\text { Village } \\
\text { Nekrasovka }\end{array}$ & $\begin{array}{l}\text { Council of tribal } \\
\text { enterprises }\end{array}$ & $\begin{array}{l}\text { Head, } \\
19.08 .2015\end{array}$ & 1 \\
\hline August 2015 & $\begin{array}{l}\text { Village } \\
\text { Nekrasovka }\end{array}$ & & $\begin{array}{l}\text { Local resident, } \\
19.08 .2015\end{array}$ & 1 \\
\hline August 2015 & $\begin{array}{l}\text { Village } \\
\text { Nekrasovka }\end{array}$ & House of culture & $\begin{array}{l}\text { Director, } \\
20.08 .2015\end{array}$ & 1 \\
\hline August 2015 & $\begin{array}{l}\text { Village } \\
\text { Nekrasovka }\end{array}$ & & $\begin{array}{l}\text { Local resident, } \\
20.08 .2015\end{array}$ & 1 \\
\hline August 2015 & Village Veni & & $\begin{array}{l}\text { Local resident, } \\
21.08 .2015\end{array}$ & 1 \\
\hline August 2015 & Village Veni & & $\begin{array}{l}\text { Local resident, } \\
21.08 .2015\end{array}$ & 1 \\
\hline October 2013 & Moscow & $\begin{array}{l}\text { "Exxon Neftegas } \\
\text { Limited" }\end{array}$ & $\begin{array}{l}\text { Vise president, transcript } \\
\text { of the presentation } \\
\text { at the conference } \\
\text { "Indigenous people and } \\
\text { industries: collaboration, } \\
\text { perspectives, challenges" } \\
10.2013 \text {. }\end{array}$ & 1 \\
\hline October, 2013 & Moscow & «Sakhali Energy» & $\begin{array}{l}\text { Vice chair on public } \\
\text { relations, transcript } \\
\text { of the presentation } \\
\text { at the conference } \\
\text { "Indigenous people and } \\
\text { industries: collaboration, } \\
\text { perspectives, challenges" } \\
10.2013 \text {. }\end{array}$ & 1 \\
\hline September 2013 & Yuzno Sakhalinsk & $\begin{array}{l}\text { «Sakhalin } \\
\text { Environmental Watch» }\end{array}$ & $\begin{array}{l}\text { Staff person, } \\
\text { head } \\
09.2013 \text {. }\end{array}$ & $\begin{array}{l}1 \\
1\end{array}$ \\
\hline
\end{tabular}

(Continued) 
Table 2. (Continued)

\begin{tabular}{|c|c|c|c|c|}
\hline Dates of travel & $\begin{array}{l}\text { Place of } \\
\text { interview }\end{array}$ & $\begin{array}{l}\text { Professional } \\
\text { affiliation }\end{array}$ & $\begin{array}{l}\text { position } \\
\text { date of the interview }\end{array}$ & $\begin{array}{l}\text { Number of } \\
\text { interviews }\end{array}$ \\
\hline September 2013 & village Nogliki & $\begin{array}{l}\text { Museum of natural } \\
\text { history }\end{array}$ & Vise director, 09.2013 . & 1 \\
\hline September 2013 & village Nogliki & $\begin{array}{l}\text { Nogliki public } \\
\text { administration }\end{array}$ & $\begin{array}{l}\text { Specialist in public } \\
\text { relations and the Media } \\
09.2013 \text {. }\end{array}$ & 1 \\
\hline September 2013 & village Nogliki & Hotel Kuban & $\begin{array}{l}\text { Owner, } \\
09.2013\end{array}$ & 1 \\
\hline September 2013 & village Nogliki & $\begin{array}{l}\text { Territorial tribal } \\
\text { enterprise of } \\
\text { Indigenous people }\end{array}$ & $\begin{array}{l}\text { Head, } \\
09.2013\end{array}$ & 1 \\
\hline September 2013 & Korsakov & & Local activist, 09.2013 & 1 \\
\hline September 2013 & village Nogliki & Library & $\begin{array}{l}\text { Director, } \\
09.2013\end{array}$ & 1 \\
\hline September 2013 & Yuzno Sakhalinsk & $\begin{array}{l}\text { "Sakhalin Energy», } \\
\text { Also Regional } \\
\text { Council of Authorized } \\
\text { Representatives of } \\
\text { Indigenous people }\end{array}$ & Representative, 09.2013 & 1 \\
\hline September 2013 & Yuzno Sakhalinsk & "Sakhalin Energy» & $\begin{array}{l}\text { Начальник управления } \\
\text { по связям с } \\
\text { общественностью, } \\
09.2013\end{array}$ & 1 \\
\hline September 2013 & Yuzno Sakhalinsk & «Sakhalin Energy» & Staff person, 09.2013 & 1 \\
\hline September 2013 & Yuzno Sakhalinsk & Rosprirodnadzor & $\begin{array}{l}\text { Head of the water } \\
\text { department, } 09.2013\end{array}$ & 1 \\
\hline September 2013 & Village Nogliki & Rosprirodnadzor & staff, 09.2013 & 1 \\
\hline September 2013 & Yuzno Sakhalinsk & $\begin{array}{l}\text { Museum of Natural } \\
\text { History }\end{array}$ & $\begin{array}{l}\text { Director, } \\
09.2013\end{array}$ & 1 \\
\hline September 2013 & Yuzno Sakhalinsk & $\begin{array}{l}\text { "Exxon Neftegas } \\
\text { Limited" }\end{array}$ & Representative, 09.2013 & 1 \\
\hline September 2013 & Village Val & $\begin{array}{l}\text { "Sakhalin Energy» } \\
\text { Indigenous peoples } \\
\text { Council }\end{array}$ & $\begin{array}{l}\text { Specialist on public } \\
\text { relations, } \\
\text { member, } \\
09.2013\end{array}$ & 1 \\
\hline October 2013 & Moscow & $\begin{array}{l}\text { Association of } \\
\text { Indigenous minorities } \\
\text { on the North, Siberia } \\
\text { and Far East }\end{array}$ & $\begin{array}{l}\text { Vice president, } \\
10.2013\end{array}$ & 1 \\
\hline September 2013 & Yuzno-Sakhalinsk & $\begin{array}{l}\text { Executive committee } \\
\text { of Indigenous } \\
\text { Minorities assistance } \\
\text { plan, Sakhalin Energy }\end{array}$ & $\begin{array}{l}\text { Member of the council, } \\
09.2013\end{array}$ & 1 \\
\hline
\end{tabular}




\begin{tabular}{|c|c|c|c|c|}
\hline Dates of travel & $\begin{array}{l}\text { Place of } \\
\text { interview }\end{array}$ & $\begin{array}{l}\text { Professional } \\
\text { affiliation }\end{array}$ & $\begin{array}{l}\text { position } \\
\text { date of the interview }\end{array}$ & $\begin{array}{l}\text { Number of } \\
\text { interviews }\end{array}$ \\
\hline September 2013 & Village Val & Local administration & $\begin{array}{l}\text { Member of the } \\
\text { consultative committee } \\
\text { on the side of Indigenous } \\
\text { peoples, } \\
09.2013\end{array}$ & 1 \\
\hline September 2013 & Village Val & & Local resident, 09.2013 & 1 \\
\hline September 2013 & Village Val & Local administration & Staff person, 09.2013 & 1 \\
\hline September 2013 & Village Val & $\begin{array}{l}\text { "Exxon Neftegas } \\
\text { Limited" } \\
\text { Head of the reindeer } \\
\text { herding enterprise }\end{array}$ & $\begin{array}{l}\text { Specialist on public } \\
\text { relations, } \\
\text { Reindeer herder } 09.2013\end{array}$ & 1 \\
\hline September 2013 & $\begin{array}{l}\text { Village } \\
\text { Nekrasovka }\end{array}$ & $\begin{array}{l}\text { Civil chamber under } \\
\text { the government of } \\
\text { Sakhalin Oblast } \\
\text { Rosneft } \\
\text { Kich-kich }\end{array}$ & $\begin{array}{l}\text { member, specialist } \\
\text { of public relations at } \\
\text { Rosneft } \\
\text { local activist, } \\
09.2013\end{array}$ & 1 \\
\hline September 2013 & village Nogliki & $\begin{array}{l}\text { Department on } \\
\text { Social Affairs and } \\
\text { Indigenous issues at } \\
\text { local administration }\end{array}$ & $\begin{array}{l}\text { Staff person, } \\
09.2013\end{array}$ & 1 \\
\hline September 2013 & village Nogliki & $\begin{array}{l}\text { Department on } \\
\text { Social Affairs and } \\
\text { Indigenous issues at } \\
\text { local administration }\end{array}$ & $\begin{array}{l}\text { Staff person, } \\
09.2013\end{array}$ & 1 \\
\hline September 2013 & village Nogliki & Library & $\begin{array}{l}\text { Methodology } \\
\text { Department, } \\
09.2013\end{array}$ & 1 \\
\hline September 2013 & Yuzno Sakhalinsk & $\begin{array}{l}\text { State Duma of } \\
\text { Sakhalin oblast }\end{array}$ & $\begin{array}{l}\text { Indigenous peoples' } \\
\text { representative, } \\
09.2013\end{array}$ & 1 \\
\hline September 2013 & $\begin{array}{l}\text { Village } \\
\text { Nekrasovka }\end{array}$ & & Local resident, 09.2013 & 1 \\
\hline September 2013 & $\begin{array}{l}\text { Village } \\
\text { Nekrasovka }\end{array}$ & & Local resident, 09.2013 & 1 \\
\hline September 2013 & Okha & & Local resident, 09.2013 & 1 \\
\hline September 2013 & $\begin{array}{l}\text { Village } \\
\text { Nekrasovka }\end{array}$ & School №4 & $\begin{array}{l}\text { Teacher, } \\
09.2013\end{array}$ & 1 \\
\hline September 2013 & $\begin{array}{l}\text { Village } \\
\text { Nekrasovka }\end{array}$ & School №4 & $\begin{array}{l}\text { Vice director on child } \\
\text { development, } \\
09.2013\end{array}$ & 1 \\
\hline
\end{tabular}

